\title{
Pemanfaatan Kitin Udang Sebagai Penyerap Timbal dan Tembaga pada Limbah Cair Industri Batik di Solo
}

\author{
Usage of Prawn Chitin as Absorber of Lead (Pb) and Copper (Cu) from Waste Water of \\ Batik Industry in Solo
}

\author{
Martinus Dwi Cahyanto, Yuniarti Aida*, F. Sinung Pranata \\ Fakultas Teknobiologi, Universitas Atma Jaya Yogyakarta, Jl. Babarsari 44 Yogyakarta 55281 \\ E-mail: yuniaida@hotmail.com*Penulis untuk korespondensi
}

\begin{abstract}
The waste of shrimps in the form of skin, head, and tail that is disposed from shrimp processing and disposal are usually thrown away with out being processed, therefore the wastes may cause environmental pollution, especially from the unpleasant stench. Shrimp wastes contain compounds called chitin and can be utilized to absorb heavy metals which are mainly from industrial wastes. The batik industries in Solo usually utilize synthetic colors, because synthetic colors are cheaper and can make the products look more satisfying. Nevertheless, the liquid wastes from these batik industries are usually still colorful when it is disposed and are usually hard to be degraded by nature. Moreover, these wates contains heavy metals such as lead $(\mathrm{Pb})$ and copper $(\mathrm{Cu})$ that can endanger the human health. This research is conducted in order to notify the performance of chitin in order to absorb heavy metals such as lead $(\mathrm{Pb})$ and copper $(\mathrm{Cu})$. There are five treatments that is conducted in this research by adding chitin powder as much as $\mathbf{0} \mathrm{g}$ (control), 1, 2, 3 and $\mathbf{4} \mathrm{g}$ into the sample of batik liquid wastes. The lead $(\mathrm{Pb})$ and copper $(\mathrm{Cu})$ substance of the sample will then be measured using the AAS (Atomic Absorption Spectrophotometer), then the lead (Pb) and copper $(\mathrm{Cu})$ substance of each treatment will be compared with the control. The result of the research shows that chitin can reduce the content of lead and copper in batik liquid wastes. Based on the research result, it is concluded that the addition of 4 $\mathrm{g}$ of chitin powder into the sample of batik liquid wastes can give the most maximum result, i.e. the reduction of the $\mathrm{Pb}$ content by $6.138 \mathrm{ppm}$ from the control of 17.773 ppm into 11,635 ppm, and the reduction of the $\mathrm{Cu}$ content by $3.779 \mathrm{ppm}$ from the control of $7.903 \mathrm{ppm}$ into $4.104 \mathrm{ppm}$.
\end{abstract}

Key words: chitin, waste water, heavy metals

Diterima: 08 Desember 2007, disetujui: 28 Januari 2008

\section{Pendahuluan}

Limbah yang dihasilkan dari proses pembekuan udang, pengalengan udang, pengolahan kerupuk udang, dan pengolahan udang lainnya berkisar antara 30\% - 75\% dari berat udang, dengan demikian jumlah bagian yang terbuang dari usaha pengolahan udang cukup tinggi (Marganof, 2003). Limbah udang yang berupa kulit, kepala, dan ekor dengan mudah didapatkan, dan di dalamnya mengandung senyawa kimia berupa kitin dan kitosan (Manjang, 1993). Limbah udang tersebut memang benar-benar harus dimanfaatkan, karena limbah yang terbuang dari usaha pengolahan udang tersebut hanya terbuang percuma tanpa diolah terlebih dahulu sehingga menyebabkan pencemaran lingkungan, terutama dari bau tak sedap yang dihasilkan.

Pemanfaatan limbah udang yang dihasilkan dari usaha pengolahan udang tersebut salah satunya adalah dengan 
memanfaatkan senyawa yang terkandung dalam limbah udang tersebut, senyawa tersebut adalah kitin. Kitin udang tersebut memiliki banyak manfaat, menurut Marganof (2003), kitin dan kitosan yang diperoleh dari limbah kulit udang digunakan sebagai absorben untuk menyerap ion logam berat dalam perairan dengan cara dinamis, yaitu dengan mengatur kondisi penyerapan sehingga air yang dibuang ke lingkungan menjadi air yang bebas dari ionion logam berat.

Kitin mempunyai rumus molekul $\mathrm{C}_{18} \mathrm{H}_{26} \mathrm{~N}_{2} \mathrm{O}_{10}$ merupakan zat padat yang tak berbentuk (amorphous), tak larut dalam air, asam anorganik encer, alkali encer dan pekat, alkohol, dan pelarut organik lainnya tetapi larut dalam asam-asam mineral yang pekat. Kitin kurang larut dibandingkan dengan selulosa dan merupakan N-glukosamin yang terdeasetilasi sedikit, sedangkan kitosan adalah kitin yang terdeasetilasi sebanyak mungkin (Marganof, 2003). Menurut Richards (1951), secara kimiawi kitin merupakan polimer (1-4)-2asetamido-2-deoksi- $\beta$-D- glukosamin yang dapat dicerna oleh mamalia.

Penelitian ini menggunakan sampel berupa limbah cair batik yang diambil di salah satu industri batik yang ada di Solo. Zat warna yang biasa digunakan pada industri batik umumnya zat warna sintetik, karena harganya murah dan memberikan hasil yang lebih memuaskan, tetapi limbah yang dihasilkan masih berwarna dan sulit terdegradasi oleh lingkungan, sehingga dapat mengganggu estetika maupun penetrasi sinar matahari ke dalam badan air yang pada gilirannya akan menurunkan kualitas lingkungan karena efek bahan berbahaya yang terkandung di dalamnya (Soedarsono dan Syahputra, 1996).

Proses pembuatan batik yang paling banyak menimbulkan pencemaran adalah proses basah, yaitu pekerjaan batik dalam larutan zat kimia dengan air sebagai mediumnya dan sebagai bahan pembantu yang terdiri dari kanji, minyak, lilin, soda $(\mathrm{NaOH})$, deterjen dan bahan pewarna. Berdasarkan survei pendahuluan bak-bak pengendap air limbahnya sebelum air limbah tersebut dibuang langsung ke badan air. Namun demikian pada bak-bak pengendap air limbah tersebut belum cukup mengatasi pencemaran yang ditimbulkan. Hal ini terbukti dengan adanya hasil pemeriksaan awal warna air limbah batik sebesar 266 Pt-Co, belum lagi kandungan logam berat seperti $\mathrm{Pb}, \mathrm{Cd}$, dan $\mathrm{Cu}$ yang paling sering terkandung pada limbah cair industri tekstil (Soedarsono dan Syahputra, 1996).

Menurut Darmono (1995), logam berat $\mathrm{Pb}$ dan $\mathrm{Cu}$ dapat terakumulasi dalam tubuh manusia dan akan sangat berbahaya bila mencapai kadar tertentu. Biasanya orang yang keracunan $\mathrm{Pb}$ mengkonsumsi sekitar 0,2-2,0 $\mathrm{mg} \mathrm{Pb} /$ hari dan $\mathrm{Pb}$ tersebut akan terakumulasi di dalam tubuh manusia, sedangkan menurut Effendi (2003), kadar $\mathrm{Cu}$ maksimum pada air minum adalah $0,1 \mathrm{mg}$, selebihnya akan berbahaya bagi tubuh manusia.

Penelitian ini untuk mengetahui kemampuan senyawa kitin yang dihasilkan dari limbah udang untuk menyerap logam berat berupa $\mathrm{Pb}$ dan $\mathrm{Cu}$ pada limbah cair dari salah satu industri batik di Solo, selain itu untuk mengetahui tingkat penyerapan yang paling tinggi dari kadar logam berat $\mathrm{Pb}$ dan $\mathrm{Cu}$ pada sampel limbah cair batik dengan pemberian serbuk kitin udang sebanyak 1, 2, 3 dan 4g.

\section{Metode Penelitian}

Limbah udang yang telah dikumpulkan setelah melalui proses demineralisasi dengan $\mathrm{HCl} 5 \%$ dan proses deproteinasi dengan $\mathrm{NaOH}$ 5\% akan menghasilkan bahan yang berbentuk serbuk yaitu serbuk kitin. Sampel limbah cair batik diambil $100 \mathrm{ml}$ kemudian masing-masing ditempatkan pada 5 buah erlenmeyer kapasitas $250 \mathrm{ml}$. Selanjutnya, dilakukan variasi penambahan serbuk kitin udang pada masingmasing tabung, yaitu pada tabung A tidak di tambah kitin udang (kontrol), tabung B ditambah 1 gram kitin, tabung $\mathrm{C}$ ditambah 2 gram kitin, tabung $\mathrm{D}$ ditambah 3 gram kitin, tabung $\mathrm{E}$ ditambah 4 gram kitin, kemudian masing-masing tabung digojog hingga kitin terendam semua. Lima tabung tersebut kemudian digojog menggunakan shaker selama 24 jam. Setelah 24 jam, kelima erlenmeyer tersebut diambil kemudian dibiarkan selama \pm 2-3 jam agar terjadi pengendapan. Setelah 2-3 jam sampel dilihat dan diamati pengendapan yang terjadi, kemudian masing-masing sampel 
diambil $\pm 20 \mathrm{ml}$ secara perlahan-lahan agar endapan tidak ikut terambil, kemudian sampel dimasukkan ke dalam 5 buah botol film yang sudah dilabel hingga penuh dan siap untuk diuji dengan AAS. Hasil pengukuran logam berat $\mathrm{Pb}$ dan $\mathrm{Cu}$ dengan alat AAS (Atomic absorbtion Spectrophotomethry) pada kelima perlakuan masing-masing dibandingkan dengan kontrol dan dihitung penurunan yang terjadi.

\section{Hasil dan Pembahasan}

Menurut Anonim (2006), dikatakan bahwa isolasi kitin dari kulit udang/kepiting biasanya dilakukan dalam tiga tahap. Tahap pertama adalah penghilangan mineral (demineralisasi), tahap kedua adalah tahap penghilangan protein (deproteinasi), dan tahap ketiga adalah tahap penghilangan warna. Tahap penghilangan warna dapat dilakukan atau tidak, tergantung keperluan. Setelah melalui ketiga tahap tersebut, biasanya akan diperoleh kitin, dari $1 \mathrm{~kg}$ kulit udang kering, biasanya akan diperoleh kitin sebanyak 200 - 250 gram.

Hasil pembuatan serbuk kitin dari kulit udang pada penelitian ini dapat dilihat pada Tabel 1.

Berdasarkan hasil pembuatan kitin pada penelitian ini, dapat dilihat bahwa pembuatan kitin masing-masing $100 \mathrm{~g}$ kulit udang kering dalam 5 kali pembuatan, dapat menghasilkan rata-rata serbuk kitin sebanyak 22,082 g dan berat total kitin yang dihasilkan adalah sebanyak 110,41 gram dari 500 gram kulit udang. Hasil serbuk kitin tersebut sangat menurun drastis dari berat awal kulit udang, hal ini disebabkan karena kandungan zat seperti protein, mineral, dan kalsium yang ada pada kulit udang sudah ikut larut pada asam kuat dan basa kuat yang digunakan yaitu $\mathrm{HCl}$ dan $\mathrm{NaOH}$.

Setelah digojog menggunakan shaker selama 24 jam, sampel limbah batik yang telah ditambahkan serbuk kitin tampak menunjukkan terjadinya pengendapan yang semakin meningkat seiring dengan semakin banyaknya penambahan serbuk kitin. Pada sample penambahan $4 \mathrm{~g}$ serbuk kitin menunjukkan pengendapan yang paling tinggi dibandingkan sampel yang lain. Berdasarkan pengamatan dari hasil tersebut, ternyata pada sample penambahan $4 \mathrm{~g}$ serbuk kitin warnanya terlihat paling jernih dibandingkan sampel yang lain dan menunjukkan proses pengendapan yang paling tinggi, hal ini disebabkan karena serbuk kitin tersebut berperan sebagai koagulan yang dapat mengurangi daya tolak menolak antar partikel koloid, sehingga partikel-partikel tersebut dapat bergabung menjadi flok-flok kecil. Flok-flok kecil hasil proses koagulasi akan terkumpul menjadi flok-flok berukuran besar sehingga mudah mengendap, jadi semakin banyak pemberian serbuk kitin maka proses pengendapan yang terjadi juga akan semakin tinggi dan menyebabkan warna sampel air limbah menjadi semakin jernih.

Flokulasi adalah proses penggabungan flok-flok kecil hasil proses koagulasi menjadi flok-flok berukuran besar sehingga mudah mengendap (Mujiadi dan Nieke, 2001).

Tabel 1. Hasil jadi pembuatan kitin per $100 \mathrm{~g}$ kulit udang

\begin{tabular}{ccc}
\hline \hline No & Berat Kulit Udang Awal & Hasil Kitin \\
\hline \hline 1 & 100 gram & 17,7 gram \\
2 & 100 gram & 22 gram \\
3 & 100 gram & 24,2 gram \\
4 & 100 gram & 24,17 gram \\
5 & 100 gram & 22,34 gram \\
\hline \hline Total & $\mathbf{5 0 0}$ gram & $\mathbf{1 1 0 , 4 1}$ gram \\
Rata-rata & $\mathbf{1 0 0}$ gram & $\mathbf{2 2 , 0 8 2}$ gram \\
\hline \hline
\end{tabular}


Hasil pengukuran kadar $\mathrm{Pb}$ pada limbah cair industri batik dengan variasi banyaknya kitin udang (1g, 2g, 3g, 4g / $100 \mathrm{ml}$ sampel) (Tabel 2 dan Gambar 1).

Berdasarkan hasil pengukuran kadar $\mathrm{Pb}$ limbah cair industri batik pada Tabel 2, setiap penambahan serbuk kitin tampak menunjukkan hasil yang berbeda nyata pada setiap perlakuan. Hasil pada penambahan serbuk kitin sebanyak 4 gram menunjukkan hasil yang paling maksimal, yaitu dapat menurunkan kadar logam $\mathrm{Pb}$ mencapai 6,138 ppm dari kadar $\mathrm{Pb}$ kontrol sebesar 17,773 ppm menjadi 11,635 ppm. Hasil tersebut dikarenakan pada penambahan kitin 4 gram menunjukkan proses pengendapan yang paling tinggi. Logam berat $\mathrm{Pb}$ yang terkandung pada limbah cair batik tersebut ikut terbawa pada endapan yang dihasilkan, maka dari peristiwa pengendapan tersebut ion logam $\mathrm{Pb}$ yang terkandung pada limbah cair batik menjadi menurun.

Hasil pengukuran kadar $\mathrm{Cu}$ pada limbah cair industri batik dengan variasi banyaknya kitin udang (1, 2, 3, 4g / $100 \mathrm{ml}$ sampel) dapat dilihat pada Tabel 3 dan Gambar 2.

Berdasarkan hasil pengukuran kadar $\mathrm{Cu}$ limbah cair industri batik pada Tabel 3, setiap penambahan serbuk kitin tampak menunjukkan hasil yang berbeda nyata pada setiap perlakuan. Hasil pada penambahan serbuk kitin sebanyak 4 gram menunjukkan hasil yang paling maksimal, yaitu dapat menurunkan kadar $\mathrm{Cu}$ mencapai 3,799 ppm dari kadar $\mathrm{Cu}$ kontrol sebesar 7,903 ppm menjadi 4,104 ppm. Hasil tersebut dikarenakan pada penambahan kitin 4 gram menunjukkan proses pengendapan yang paling tinggi. Logam $\mathrm{Cu}$ yang terkandung pada limbah cair batik tersebut ikut terbawa pada endapan yang dihasilkan, maka dari peristiwa pengendapan tersebut logam $\mathrm{Cu}$ yang terkandung pada limbah cair batik akan menunjukkan penurunan.

Benaissa dan Benguella (2003), mengatakan bahwa penggunaan kitin yang tidak diberi perlakuan apapun sebanyak 2 gram yang dimasukkan pada $100 \mathrm{ml}$ sampel, ternyata dapat menyerap Cd maksimum sebanyak 14.21 $\mathrm{mg} / \mathrm{g}$ kitin. Penelitian tersebut membuktikan bahwa penggunaan kitin dapat dimanfaatkan untuk menyerap ion logam berat dalam perairan.

Kitin pada penelitian ini ternyata dapat menyerap $\mathrm{Pb}$ dan $\mathrm{Cu}$, menurut Kennedy et al., (1994), hal tersebut disebabkan karena logam berat dan logam lain secara keseluruhan dalam larutan elektrolit merupakan partikel bermuatan positif, sedangkan kitin adalah polielektrolit yang bermuatan negatif, reaksi antara kedua partikel akan menuju pada arah penghilangan gradien muatan dan terbentuk senyawa produk yang tidak bermuatan. Kitin sebagai polielektrolit merupakan bagian dari polimer khusus yang dapat terionisasi dan mempunyai kemampuan untuk membuat terjadinya suatu flokulasi dalam medium cair.

Tabel 2. Rata-rata hasil pengukuran kadar timbal pada limbah cair industri batik dengan variasi banyaknya kitin udang (ppm) per $100 \mathrm{ml} \mathrm{sampel}$

\begin{tabular}{cccccc}
\hline \hline & \multicolumn{5}{c}{ Penambahan Kitin } \\
\cline { 2 - 6 } & Kontrol & $1 \mathrm{~g}$ & $2 \mathrm{~g}$ & $3 \mathrm{~g}$ & $\mathbf{4} \mathrm{g}$ \\
\hline \hline Kadar Timbal & $17,773^{\mathrm{E}}$ & $17,240^{\mathrm{D}}$ & $15,898^{\mathrm{C}}$ & $12,322^{\mathrm{B}}$ & $\mathbf{1 1 , 6 3 5}^{\mathrm{A}}$ \\
\hline \hline
\end{tabular}

Setiap angka yang diikuti dengan huruf yang sama pada kolom yang sama menunjukkan tidak beda nyata

Tabel 3. Rata-rata Hasil pengukuran kadar tembaga pada limbah cair industri batik dengan variasi banyaknya kitin udang per $100 \mathrm{ml}$ sampel

\begin{tabular}{cccccc}
\hline \hline & \multicolumn{5}{c}{ Penambahan Kitin } \\
\cline { 2 - 6 } Ulangan & kontrol & 1 g kitin & 2 g & 3 g & 4 g \\
\hline \hline Kadar Tembaga & $7,903^{\mathrm{E}}$ & $7,693^{\mathrm{D}}$ & $7,163^{\mathrm{C}}$ & $\mathbf{6 , 2 1 1}^{\mathrm{B}}$ & $\mathbf{4 , 1 0 4}^{\mathrm{A}}$ \\
\hline \hline
\end{tabular}

Setiap angka yang diikuti dengan huruf yang sama pada kolom yang sama menunjukkan tidak beda nyata 


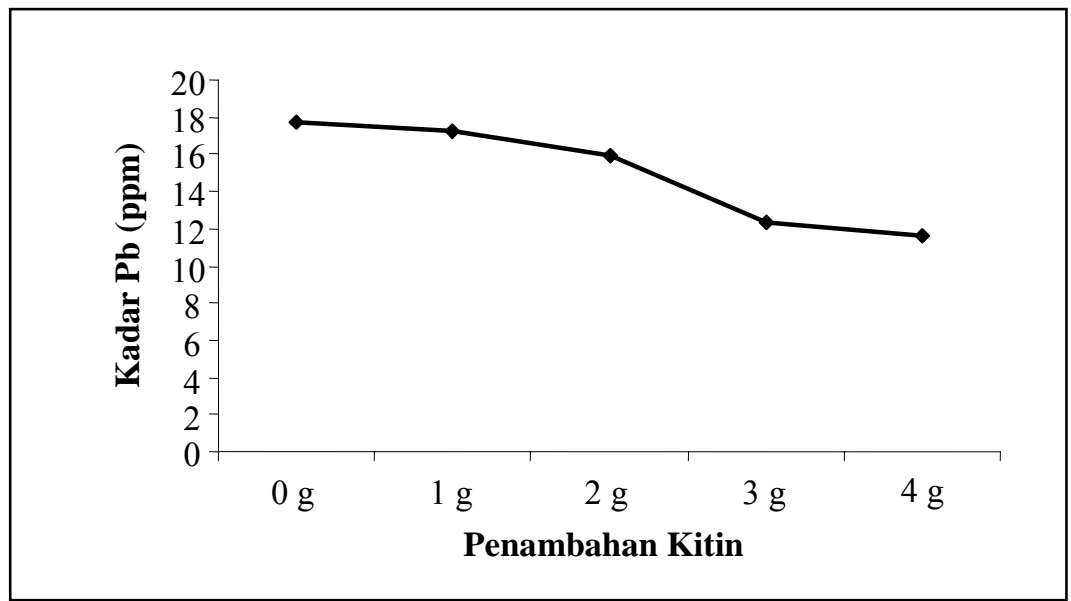

Gambar 1. Penurunan kadar $\mathrm{Pb}$ dengan variasi banyaknya kitin udang

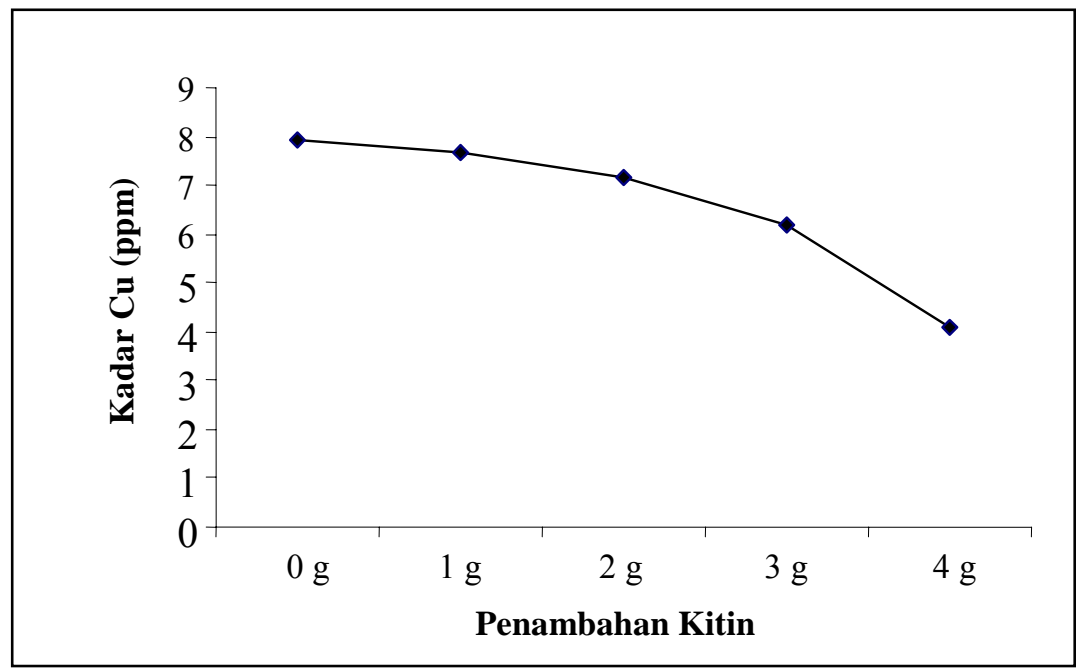

Gambar 2. Penurunan kadar $\mathrm{Cu}$ dengan variasi banyaknya kitin udang

\section{Kesimpulan}

Berdasarkan hasil penelitian dapat disimpulkan bahwa senyawa kitin yang dihasilkan dari limbah udang memiliki kemampuan untuk menyerap logam berat berupa $\mathrm{Pb}$ dan $\mathrm{Cu}$. Penambahan serbuk kitin sebanyak 4 gram kedalam sampel limbah cair batik menunjukkan hasil yang paling maksimal, dalam menurunkan kadar logam berat.

\section{Daftar Pustaka}

Anonim. 2006. Mengenal Lebih Dekat Kitosan. http:// www.exfind.de/cgi-bin/catalog.cgi.09/02/2007
Benaissa, H. and Benguella, B. 2003. Sorbtion of Cadmium From Aqueous Solutions By Chemically Pre Treated Chitin, Laboratory of Sorbent Materials and Water Treatment, Department of Chemistry Faculty of Sciences, University of Tlemcen, Algeria.

Darmono. 1995. Logam Dalam Biologi Makhluk Hidup, Penerbit Universitas Indonesia (UI Press), Jakarta.

Effendi, H. 2003. Telaah Kualitas Air Bagi Pengelolaan Sumber Daya dan Lingkungan Perairan, Penerbit Kanisius, Yogyakarta.

Kennedy, J., Marion, P., David, T. and Marisa. 1994. Recovery of Proteins from Whey Using Chitosan As A Coagulant, Biotechnology and Bioactive Polymers, In: Gebelein, C., Carraher (Eds.). Plenum Publishing, New York. 
Manjang, Y. 1993. Analisa Ekstrak Berbagai Jenis Kulit Udang terhadap Mutu Khitosan, J. Penelitian Andalas 12 (V): 138-143.

Marganof. 2003. Potensi Limbah Udang Sebagai Penyerap Logam Berat (Timbal, Kadmiun dan Tembaga) di Perairan, Program Pasca Sarjana, Institut Pertanian Bogor.

Mujiadi, S. dan Nieke, K. 2002. Kemampuan Koagulan Poli Aluminium Khloride Untuk Menurunkan Warna Effluent Pengolahan Limbah P.T Sier. J. Purifikasi 2 (V): 271-276.

Richards, A.G. 1951. The Integument of Arthropods. The Chemical Components and Their Properties: The Anatomy and Development and Permeability, University of Minnesota Press, Minneapolis.

Soedarsono dan Syahputra, B. 1996, Pengolahan Air Limbah Batik Dengan Proses Kombinasi Elektrokimia, Filtrasi, dan Adbsorbsi, Fakultas Teknik Jurusan Teknik Lingkungan Universitas Islam Sultan Agung (UNISSULA) Semarang.(http://www.google.co.id/pengolah an air limbah batik/elektroforesis) 01/13/2008. 